\title{
Qualitative feed restriction for heavy swines: effect on digestibility and weight of organs of digestive tract, and environmental impact of feces
}

\author{
[Restrição alimentar qualitativa para suínos pesados: efeito sobre digestibilidade e peso dos órgãos do trato \\ digestório e impacto ambiental das fezes] \\ A.L. Fraga ${ }^{1,7}$, M.C. Thomaz ${ }^{2}$, R.N. Kronka ${ }^{2}$, F.E.L. Budiño ${ }^{3}$, R.A.R. Huaynate ${ }^{4}$, A.J. Scandolera ${ }^{5}$, \\ U.S. Ruiz ${ }^{4}$ A. Nadai ${ }^{6}$ \\ ${ }^{1}$ In memorian \\ ${ }^{2}$ Faculdade de Ciências Agrárias e Veterinárias - UNESP - Jaboticabal, SP \\ ${ }^{3}$ Instituto de Zootecnia - APTA/SAA - Nova Odessa, SP \\ ${ }^{4}$ Aluno de pós-graduação - FCAV-UNESP - Jaboticabal, SP \\ ${ }^{5}$ Universidade Federal do Paraná - Curitiba, PR \\ ${ }^{6}$ Agroceres Nutrição Animal - Patos de Minas, MG \\ ${ }^{7}$ Bolsista da FAPESP
}

\begin{abstract}
A total of 50 barrows were used to evaluate qualitative feed restriction on digestibility of dietary components, weight of organs of digestive tract, and composition and production of feces. Five experimental diets, with increasing levels of qualitative feed restriction of $0,5,10,15$, and $20 \%$ were used. There was linear reduction $(\mathrm{P}<0.001)$ of all digestibility coefficients on the levels of qualitative feed restriction, except for acid detergent fiber, which presented a quadratic response $(\mathrm{P}<0.05)$. Contents of total solids $(\mathrm{P}<0.01)$, volatile solids $(\mathrm{P}<0.05)$, and total minerals $(\mathrm{P}<0.001)$ in the feces augmented with increasing levels of qualitative feed restriction, whereas the levels of $\mathrm{K}(\mathrm{P}<0.05), \mathrm{Cu}(\mathrm{P}<0.01), \mathrm{N}, \mathrm{P}, \mathrm{Na}, \mathrm{Ca}, \mathrm{Mg}, \mathrm{Fe}$, and $\mathrm{Zn}(\mathrm{P}<0.001)$ presented a quadratic response. Daily feces excretion; and contents of total solids, volatile solids, total minerals, and levels of $\mathrm{N}, \mathrm{P}, \mathrm{K}, \mathrm{Mn}$, and $\mathrm{Cu}(\mathrm{P}<0.001)$ and $\mathrm{Ca}, \mathrm{Na}, \mathrm{Mg}$, and $\mathrm{Fe}(\mathrm{P}<0.05)$ presented a clear increase in function of the qualitative feed restriction level. Qualitative feed restriction can be an alternative for the disposal of agribusiness waste, providing good crop-fertilizing by the use of swine feces.
\end{abstract}

Keywords: swine, fecal composition, energy dilution, mineral excretion, fermentable fiber, insoluble fiber

\section{RESUMO}

Foram utilizados 50 suínos machos castrados para avaliar o efeito da restrição alimentar qualitativa sobre a digestibilidade dos componentes dietéticos, os órgãos do trato digestório, a composição e a produção fecal. Foram utilizadas cinco dietas experimentais, com níveis de restrição qualitativa de 0, 5, 10, 15 e 20\%. Houve redução linear $(P<0,001)$ para todos os coeficientes de digestibilidade, com exceção da fibra em detergente ácido, que apresentou resposta quadrática $(P<0,05)$. Os teores de sólidos totais $(P<0,01)$ e voláteis $(P<0,05)$, e minerais totais $(P<0,001)$ nas fezes aumentaram com os niveis de restrição alimentar, enquanto os níveis de $K(P<0,05), C u(P<0,01)$ e de $N, P, N a, C a, M g, F e ~ e ~ Z n ~(P<0,001)$, apresentaram resposta quadrática. $A$ excreção diária de fezes, sólidos totais e voláteis, minerais totais, $N, P, K, M n$ e $C u(P<0,001), C a, N a, M g$ e Fe $(P<0,05)$ apresentaram aumento em função do nível da restrição alimentar qualitativa. A restrição qualitativa pode ser alternativa para destinação de resíduos da agroindústria, conferindo boas propriedades às fezes suínas, no que diz respeito à utilização para adubação de culturas.

Palavras-chave: suíno, composição fecal, diluição de energia, excreção mineral, fibra fermentável, fibra insolúvel

Recebido em 17 de junho de 2008

Aceito em 3 de agosto de 2009

*Autor para correspondência (corresponding author)

E-mail: thomaz@fcav.unesp.br 


\section{INTRODUCTION}

The production of swine to be slaughtered at heavier weights must take into account nutritional strategies that reduce fat deposition in the carcass. Therefore, the control of energy intake is important. The inclusion of low-energy ingredients to animal feeds may reduce their body energy content, thereby promoting qualitative feed restriction for swine. Ingredients used for this purpose must be highly available and inexpensive, and usually consists of fiberrich byproducts derived from agricultural raw material processing.

However, the use of fibrous ingredients may have adverse effects on diet digestibility, mainly due to fiber composition, depending on the animal class do be fed (Noblet and LeGoff, 2001). The use of fiber by swine increases with animal weight. In addition, the environmental impact of changes in the diet formulations for finishing swine is much higher than those for gestating females due to the higher number of the former, particularly taking into account that nutrition is one of the most important factors causing waste production in swine raising (Penz Jr., 2000).

This study evaluated the effect of qualitative feed restriction as obtained by the inclusion of rice hulls on the digestibility of dietary nutrients, weights of organs of digestive tract, excretion, and fecal composition of heavy swines.

\section{MATERIAL AND METHODS}

A total of 50 barrows $(89.0 \pm 4.5 \mathrm{~kg})$ were brought to the Swine Production Sector at the Departamento de Ciência Animal at FCAV/UNESP and were housed in individual pens $\left(2.55 \mathrm{~m}^{2}\right)$. Each pen was equipped with semi-automatic feeder, level drinker, and bar divisions.

A randomized block experimental design was applied, with five treatments and ten blocks per treatment. Blocks were used to control individual differences in initial weight.

$$
\begin{aligned}
\mathrm{DC}_{\text {nutrient }}= & \left(\left[\mathrm{Cr}_{2} \mathrm{O}_{3 \text { feces }}\right] /\left[\mathrm{Cr}_{2} \mathrm{O}_{3 \text { diet }}\right]\right) \times\left(\left[\text { nutrient }_{\text {diet }}\right] /\left[\text { nutrient }_{\text {feces }}\right]\right) \\
& \text { Digestible Nutrient } \\
\text { diet } & =\left[\text { nutrient }_{\text {diet }}\right] \times \mathrm{DC}_{\text {nutrient }}
\end{aligned}
$$

The treatments consisted of five experimental diets, formulated to supply $0,5,10,15$, and $20 \%$ qualitative feed restriction, as shown in Table 1. Diets were formulated to contain equal levels of digestible lysine, calcium, and available phosphorus. Animals remained in the experiment until averaging $128 \mathrm{~kg}$ body weight, when they were slaughtered.

Daily excretion of feces was determined by the average of these two collections. After weighing, feces from each pen were homogenized, and $20 \%$ (subsample) was placed in plastic bags and frozen $\left(-20^{\circ} \mathrm{C}\right)$.

In the beginning of the third experimental week, $0.4 \%$ chromium oxide $\left(\mathrm{Cr}_{2} \mathrm{O}_{3}\right)$ was added to the diet as digestibility marker. After three days, feces were directly collected from the rectum of all animals twice a day for three days. The samples were weighed to be included in the daily waste production calculation, and then placed in plastic bags and frozen $-20^{\circ} \mathrm{C}$. At the time of the analyses, all samples relative to the same individual animal, were homogenized, composing a single sample for digestibility analysis. After thawing, all fecal samples were pre-dried in a forced-ventilation oven at $65^{\circ} \mathrm{C}$ for 72 hours, and were processed in a "knife" mill, with a 1-mm mesh, and were stored in plastic containers until analysis.

Dry matter (DM), crude protein (CP), neutral detergent fiber (NDFc), and acid detergent fiber (ADFc), both corrected for ashes (Silva, 1990) were determined. Hemicellulose, cellulose, and lignin were also determined for the experimental diets. Chromium oxide contents in feces and feeds were analyzed, according to Fenton e Fenton (1979). Gross energy (GE) and ether extract (EE) contents were determined according to Silva (1990).

The coefficients of digestibility (DC) of GE, CP, $\mathrm{EE}, \mathrm{NDFc}$, and ADFc, as well as the digestible content of these nutrients in each experimental diet were calculated using the equations described by Oetting (2002), as follows: 
Qualitative feed restriction for heavy...

Table 1. Percentage of ingredients chemical and energetic compositions of the experimental diets and rice hulls used as dietary ingredient for swines

\begin{tabular}{|c|c|c|c|c|c|c|}
\hline \multirow{2}{*}{ Ingredients } & \multicolumn{5}{|c|}{ Qualitative feed restriction, $\%$} & \multirow{2}{*}{$\begin{array}{l}\text { Rice } \\
\text { hulls }\end{array}$} \\
\hline & 0 & 5 & 10 & 15 & 20 & \\
\hline Corn, $\%$ & 83.99 & 78.67 & 73.36 & 68.04 & 62.73 & - \\
\hline Soybean meal, \% & 14.34 & 14.77 & 15.20 & 15.63 & 16.06 & - \\
\hline Rice hulls, $\%$ & - & 4.94 & 9.83 & 14.72 & 19.60 & - \\
\hline Calcitic limestone, $\%$ & 0.767 & 0.745 & 0.723 & 0.702 & 0.680 & - \\
\hline Dicalcium phosphate, $\%$ & 0.300 & 0.319 & 0.337 & 0.356 & 0.375 & - \\
\hline Salt, $\%$ & 0.250 & 0.250 & 0.250 & 0.250 & 0.250 & - \\
\hline Mineral supplement ${ }^{(1)}, \%$ & 0.150 & 0.150 & 0.150 & 0.150 & 0.150 & - \\
\hline Vitamin supplement $^{(1)}, \%$ & 0.150 & 0.150 & 0.150 & 0.150 & 0.150 & - \\
\hline \multicolumn{7}{|l|}{ Composition ${ }^{(2)}$} \\
\hline Gross energy, $\mathrm{kcal} / \mathrm{kg}$ & 3,957 & 3,904 & 3,924 & 3,878 & 3,851 & 3,416 \\
\hline $\mathrm{CP}, \%$ & 13.6 & 13.4 & 13.4 & 13.1 & 13.1 & 2.0 \\
\hline Ether Extract, \% & 3.56 & 2.88 & 2.29 & 2.05 & 1.81 & - \\
\hline $\mathrm{NDFc}^{(3)}, \%$ & 14.6 & 18.2 & 21.1 & 24.7 & 28.2 & 69.6 \\
\hline $\mathrm{ADFc}, \%$ & 4.53 & 7.84 & 10.1 & 12.9 & 16.1 & 56.1 \\
\hline Hemicellulose, $\%$ & 10.1 & 10.4 & 10.9 & 11.8 & 12.2 & 13.5 \\
\hline Cellulose, $\%$ & 3.8 & 5.8 & 7.6 & 9.4 & 11.5 & 39.4 \\
\hline Lignin, $\%$ & 1.0 & 1.7 & 2.6 & 3.4 & 4.3 & 16.6 \\
\hline \multicolumn{7}{|l|}{ Elements ${ }^{(4)}$} \\
\hline $\mathrm{N}, \%$ & 2.0 & 1.9 & 1.9 & 1.9 & 1.8 & 0.3 \\
\hline $\mathrm{P}, \%$ & 0.32 & 0.32 & 0.30 & 0.30 & 0.29 & 0.01 \\
\hline $\mathrm{K}, \%$ & 115.4 & 116.1 & 117.5 & 117.8 & 117.2 & 36.8 \\
\hline $\mathrm{Ca}, \%$ & 44.9 & 44.5 & 45.2 & 45.2 & 44.2 & 11.4 \\
\hline $\mathrm{Na}, \%$ & 14.1 & 14.2 & 14.1 & 14.1 & 14.1 & - \\
\hline $\mathrm{Mg}, \%$ & 24.2 & 24.3 & 24.1 & 24.1 & 24.1 & 8.7 \\
\hline $\mathrm{Fe}, \mathrm{ppm}$ & 139 & 131 & 121 & 113 & 102 & - \\
\hline $\mathrm{Cu}, \mathrm{ppm}$ & 64.7 & 69.9 & 67.4 & 63.0 & 65.0 & - \\
\hline $\mathrm{Mn}, \mathrm{ppm}$ & 36.4 & 47.6 & 58.2 & 72.4 & 86.3 & 158 \\
\hline $\mathrm{Zn}, \mathrm{ppm}$ & 68.7 & 77.0 & 75.7 & 80.4 & 73.7 & 8.7 \\
\hline
\end{tabular}

${ }^{1}$ Guaranteed levels per kg of feed= Fe: 60.0mg; Cu: 52.5mg; Mn: 30.0mg; Zn: 60mg; Co: 0.54mg; I: 1.26mg; Se: $0.18 \mathrm{mg}$; vit.A: $3,750 \mathrm{UI}$; vit. $\mathrm{D}_{3}: 750 \mathrm{UI}$; vit.E: $11.25 \mathrm{mg}$; vit. $\mathrm{K}_{3}: 1.5 \mathrm{mg} ; \mathrm{B}_{2}: 2.7 \mathrm{mg} ; \mathrm{B}_{12}: 10.5 \mu \mathrm{g}$; calcium pantothenate: 4.5mg; niacin: $15 \mathrm{mg}$; biotin: $0.075 \mathrm{mg}$; choline: $75 \mathrm{mg}$; antioxidant: $37.5 \mathrm{mg}$.

${ }^{2}$ Analyses were carried out at the Animal Nutrition Lab and Forage Production Lab at the Departamento de Ciência Animal and at the Anaerobic Digestion Lab at the Departamento de Engenharia Rural at the FCAV/UNESP Jaboticabal.

${ }^{3} \mathrm{NDFc}$ (neutral detergent fiber) and ADFc (acid detergent fiber), as sequentially determined and corrected for ashes.

${ }^{4}$ Determined after digestion and dilution of diets at 1:200 (Bataglia et al., 1993).

Pre-dried fecal samples for environmental impact assessment were submitted to the anaerobic biodigestion, analyzed for total solid content and total mineral content in a muffle at $550^{\circ} \mathrm{C}$ for $2 \mathrm{~h}$. Volatile solids content was calculated as the difference between total solids and total mineral contents (Massé et al., 2003). Samples of feces and experimental diets were submitted to digestion using sulfuric acid and hydrogen peroxide, obtaining an extract diluted at 1:200. In this extract, nitrogen content was determined by the Kjedahl method; phosphorus content by the molybdenum vanadate colorimetric method (Sarruge e Haag, 1974); and contents of potassium, calcium, magnesium, sodium, iron, manganese, zinc, and copper by reading in flame atomic absorption apparatus (Bataglia et al., 1993). Macro and microelement of feces were expressed on dry matter basis. Fecal composition sampled during the first four experimental weeks, before the first animals were slaughtered, were taken into consideration. 
Daily excretion of total solids and volatile solids, and total minerals, macro (N, P, K, Na, Ca, and $\mathrm{Mg}$ ) and micro ( $\mathrm{Fe}, \mathrm{Zn}, \mathrm{Mn}$, and $\mathrm{Cu}$ ) elements were calculated as the product of the amount of feces excreted daily.

Animals were submitted to feed fasting for $16 \mathrm{~h}$ before slaughter. Immediately after slaughtering and evisceration, digestive tract organs were separated. Stomach, small and large intestines, and cecum were emptied, and weighed, along with liver and pancreas, as described by Pond et al. (1988).

After normality of error distribution (ShapiroWilk test at $5 \%$ ), and homogeneity of variances (Levene test at 5\%) among treatments were tested, the obtained data were submitted to analysis of variance using the package PROC GLM of the statistical software SAS/1998.

For the variables referring to the weight of organs of digestive tract, final body weight was used as a co-variable in the model. Degrees of freedom of diets were exploded in linear and quadratic orthogonal contrasts.

\section{RESULTS}

Tables 2 and 3 show values of digestibility coefficient and digestible nutrient of the experimental diets as a function of qualitative feed restriction levels. There was a linear reduction $(\mathrm{P}<0.001)$ in all digestibility coefficients as qualitative feed restriction increased, except for ADFc, which showed a quadratic response $(\mathrm{P}<0.05)$. Digestible energy and protein dietary levels linearly reduced $(\mathrm{P}<0.001)$, whereas digestible NDFc increased $(\mathrm{P}<0.05)$ as a function of qualitative feed restriction levels. Dietary ether extract content presented a quadratic response $(\mathrm{P}<0.01)$; however, the minimum value point described by the equation was above the maximum evaluated level.

Table 2. Effect of dietary fiber on nutrient digestibility for heavy swines

\begin{tabular}{|c|c|c|c|c|c|c|}
\hline \multirow[t]{2}{*}{ Nutrient } & \multicolumn{5}{|c|}{ Qualitative feed restriction ${ }^{1}, \%$} & \multirow[t]{2}{*}{ Effect } \\
\hline & $0(\mathrm{n}=8)$ & $5(\mathrm{n}=9)$ & $10(n=9)$ & $15(n=10)$ & $20(\mathrm{n}=10)$ & \\
\hline \multicolumn{7}{|l|}{$\begin{array}{l}\text { Digestibility } \\
\text { coefficient }\end{array}$} \\
\hline Dry matter & $84.5 \pm 0.7$ & $79.0 \pm 0.6$ & $74.5 \pm 0.6$ & $70.6 \pm 0.6$ & $64.0 \pm 0.6$ & Lin. $* * *$ \\
\hline Gross energy & $84.7 \pm 0.7$ & $80.5 \pm 0.6$ & $77.3 \pm 0.6$ & $73.7 \pm 0.6$ & $68.4 \pm 0.6$ & Lin. $* * *$ \\
\hline Crude protein & $77.9 \pm 1.2$ & $76.2 \pm 1.1$ & $76.5 \pm 1.1$ & $74.1 \pm 1.0$ & $71.2 \pm 1.0$ & Lin. $* * *$ \\
\hline Ether extract & $67.9 \pm 3.0$ & $61.5 \pm 2.8$ & $52.3 \pm 2.8$ & $48.0 \pm 2.6$ & $45.2 \pm 2.6$ & Lin. $* * *$ \\
\hline $\mathrm{NDFc}$ & $59.9 \pm 1.5$ & $49.7 \pm 1.4$ & $43.9 \pm 1.4$ & $40.8 \pm 1.2$ & $33.3 \pm 1.8$ & Lin.*** \\
\hline $\mathrm{ADFc}$ & $47.6 \pm 2.7$ & $39.1 \pm 2.3$ & $26.1 \pm 2.3$ & $21.4 \pm 2.2$ & $18.9 \pm 2.2$ & Quad.* \\
\hline \multicolumn{7}{|c|}{ Digestible nutrients } \\
\hline Energy & $3,351 \pm 25$ & $3,143 \pm 24$ & $3,035 \pm 24$ & $2,890 \pm 22$ & $2,643 \pm 22$ & Lin. $* * *$ \\
\hline Protein & $10.5 \pm 0.2$ & $10.2 \pm 0.1$ & $10.3 \pm 0.1$ & $9.6 \pm 0.1$ & $9.4 \pm 0.1$ & Lin.*** \\
\hline Ether extract & $2.34 \pm 0.07$ & $1.74 \pm 0.07$ & $1.18 \pm 0.07$ & $1.08 \pm 0.06$ & $0.81 \pm 0.06$ & Quad.*** \\
\hline $\mathrm{NDFc}$ & $10.0 \pm 0.3$ & $10.4 \pm 0.3$ & $10.4 \pm 0.3$ & $11.3 \pm 0.3$ & $10.8 \pm 0.3$ & Lin. * \\
\hline $\mathrm{ADFc}$ & $2.59 \pm 0.30$ & $3.56 \pm 0.28$ & $2.96 \pm 0.28$ & $3.08 \pm 0.27$ & $3.39 \pm 0.27$ & NS \\
\hline
\end{tabular}

${ }^{1}$ adjusted means \pm standard error

$* \mathrm{P}<0.05 ; * * \mathrm{P}<0.01 ; * * * \mathrm{P}<0.001$ 
Qualitative feed restriction for heavy...

Table 3. Digestibility coefficients and digestible energy and dietary nutrient content as a function of qualitative feed restriction

\begin{tabular}{llccc}
\hline Variable & $\mathrm{b}_{0}$ & $\mathrm{~b}_{1}$ & $\mathrm{~b}_{2}$ & $\mathrm{R}^{2}$ \\
Dry matter & \multicolumn{2}{c}{ Digestibility coefficient, $\%$} & & \\
Gross energy & 84.35 & -0.98 & - & 0.99 \\
Crude protein & 84.76 & -0.78 & - & 0.99 \\
Ether extract & 78.11 & -0.27 & - & 0.91 \\
$\mathrm{NDFc}$ & 66.75 & -1.18 & - & 0.96 \\
ADFc & 57.92 & -1.24 & - & 0.97 \\
Digestible components & 48.58 & -2.67 & 0.06 & 0.98 \\
Energy & & & & \\
Protein & 3,346 & -33 & - & 0.98 \\
Ether extract & 10.56 & -0.05 & - & 0.87 \\
NDFc & 2,337 & $-0,138$ & 0,003 & 0,99 \\
\hline
\end{tabular}

Data on the weights of organs of digestive tract and their prediction equations, as a function of qualitative feed restriction, are presented in Tables 4 and 5 , respectively. There was a linear increase $(\mathrm{P}<0.05)$ in stomach weight, and linear reduction $(\mathrm{P}<0.05)$ in cecum and liver weights as qualitative feed restriction increased. There was no effect $(\mathrm{P}>0.1)$ of the treatments on the other parameters.

The effect of levels of qualitative feed restriction on feces composition and production, as well as their prediction equations, are presented in Tables $6,7,8$, and 9 .

Table 4. Effect of qualitative feed restriction on digestive tract the weights of organs of swines

\begin{tabular}{|c|c|c|c|c|c|c|}
\hline \multirow[t]{2}{*}{ Organ, kg } & \multicolumn{5}{|c|}{ Qualitative feed restriction ${ }^{1}, \%$} & \multirow[t]{2}{*}{ Effect } \\
\hline & $0(n=9)$ & $5(\mathrm{n}=9)$ & $10(n=9)$ & $15(\mathrm{n}=10)$ & $20(n=9)$ & \\
\hline Stomach & $0.60 \pm 0.02$ & $0.55 \pm 0.02$ & $0.63 \pm 0.02$ & $0.64 \pm 0.02$ & $0.63 \pm 0.02$ & Lin.* \\
\hline $\begin{array}{c}\text { Small } \\
\text { intestine }\end{array}$ & $1.48 \pm 0.08$ & $1.24 \pm 0.08$ & $1.41 \pm 0.09$ & $1.45 \pm 0.08$ & $1.46 \pm 0.09$ & - \\
\hline $\begin{array}{c}\text { Large } \\
\text { intestine }\end{array}$ & $1.63 \pm 0.08$ & $1.56 \pm 0.08$ & $1.51 \pm 0.08$ & $1.51 \pm 0.07$ & $1.49 \pm 0.08$ & - \\
\hline Cecum & $0.28 \pm 0.01$ & $0.31 \pm 0.01$ & $0.28 \pm 0.02$ & $0.27 \pm 0.01$ & $0.25 \pm 0.01$ & Lin.* \\
\hline Liver & $1.75 \pm 0.06$ & $1.65 \pm 0.06$ & $1.72 \pm 0.07$ & $1.59 \pm 0.06$ & $1.54 \pm 0.06$ & Lin.* \\
\hline Pancreas & $0.17 \pm 0.01$ & $0.17 \pm 0.01$ & $0.18 \pm 0.01$ & $0.18 \pm 0.01$ & $0.17 \pm 0.01$ & - \\
\hline
\end{tabular}

adjusted means \pm standard error

$* \mathrm{P}<0.05$

Table 5. Prediction equations of weights of organs of digestive tract of swines

\begin{tabular}{llll}
\hline Organ & $\mathrm{b}_{0}$ & $\mathrm{~b}_{1}$ & $\mathrm{R}^{2}$ \\
\hline Stomach & 0.582 & 0.003 & 0.40 \\
Cecum & 0.299 & -0.002 & 0.55 \\
Liver & 1.75 & -0.01 & 0.75 \\
\hline
\end{tabular}


Table 6. Effect of qualitative feed restriction applied to heavy swines on fecal composition

\begin{tabular}{|c|c|c|c|c|c|c|}
\hline \multirow{2}{*}{$\begin{array}{l}\text { Fecal } \\
\text { composition }\end{array}$} & \multicolumn{5}{|c|}{ Qualitative feed restriction ${ }^{1}, \%$} & \multirow[t]{2}{*}{ Effect } \\
\hline & $0(n=9)$ & $5(n=9)$ & $10(n=9)$ & $15(n=10)$ & $20(n=10)$ & \\
\hline Total solids, $\%$ & $34.5 \pm 0.9$ & $36.3 \pm 0.9$ & $36.6 \pm 0.9$ & $38.1 \pm 0.9$ & $38.4 \pm 0.9$ & Lin.** \\
\hline Volatile solids, $\%$ & $29.2 \pm 0.7$ & $30.3 \pm 0.7$ & $30.2 \pm 0.7$ & $31.2 \pm 0.7$ & $31.1 \pm 0.7$ & Lin.* \\
\hline $\begin{array}{l}\text { Total minerals, } \% \\
\text { Macroelements, } \%\end{array}$ & $5.33 \pm 0.20$ & $6.00 \pm 0.20$ & $6.35 \pm 0.20$ & $6.93 \pm 0.20$ & $7.24 \pm 0.20$ & Lin.*** \\
\hline $\mathrm{N}$ & $4.29 \pm 0.09$ & $3.38 \pm 0.09$ & $3.04 \pm 0.09$ & $2.63 \pm 0.08$ & $2.49 \pm 0.09$ & $\begin{array}{l}\text { Quad.** } \\
\text { * }\end{array}$ \\
\hline $\mathrm{P}$ & $0.92 \pm 0.02$ & $0.75 \pm 0.02$ & $0.64 \pm 0.02$ & $0.55 \pm 0.01$ & $0.51 \pm 0.01$ & $\underset{*}{\text { Quad.** }}$ \\
\hline $\mathrm{K}$ & $2.32 \pm 0.07$ & $1.92 \pm 0.07$ & $1.66 \pm 0.07$ & $1.51 \pm 0.07$ & $1.39 \pm 0.07$ & Quad.* \\
\hline $\mathrm{Ca}$ & $0.52 \pm 0.1$ & $0.41 \pm 0.1$ & $0.33 \pm 0.1$ & $0.27 \pm 0.1$ & $0.26 \pm 0.1$ & $\begin{array}{l}\text { Quad.** } \\
\text { * }\end{array}$ \\
\hline $\mathrm{Na}$ & $0.25 \pm 0.02$ & $0.19 \pm 0.02$ & $0.19 \pm 0.02$ & $0.16 \pm 0.02$ & $0.15 \pm 0.02$ & Lin. $* * *$ \\
\hline $\mathrm{Mg}$ & $0.50 \pm 0.01$ & $0.39 \pm 0.01$ & $0.33 \pm 0.01$ & $0.26 \pm 0.01$ & $0.24 \pm 0.01$ & $\begin{array}{c}\text { Quad.** } \\
\text { * }\end{array}$ \\
\hline \multicolumn{7}{|l|}{ Microelements, } \\
\hline ppm & & & & & & \\
\hline $\mathrm{Fe}$ & $1003 \pm 29$ & $778 \pm 29$ & $618 \pm 29$ & $535 \pm 29$ & $530 \pm 29$ & $\begin{array}{l}\text { Quad.** } \\
*\end{array}$ \\
\hline $\mathrm{Zn}$ & $408 \pm 22$ & $350 \pm 22$ & $298 \pm 22$ & $248 \pm 21$ & $261 \pm 21$ & Lin.*** \\
\hline $\mathrm{Mn}$ & $277 \pm 8$ & $278 \pm 8$ & $278 \pm 8$ & $271 \pm 8$ & $294 \pm 8$ & $\mathrm{NS}$ \\
\hline $\mathrm{Cu}$ & $381 \pm 16$ & $291 \pm 16$ & $244 \pm 16$ & $219 \pm 15$ & $205 \pm 15$ & Quad.** \\
\hline
\end{tabular}

Table 7. Prediction equations of feces composition of heavy swines

\begin{tabular}{lllll}
\hline Parameter & $\mathrm{b}_{0}$ & $\mathrm{~b}_{1}$ & $\mathrm{~b}_{2}$ & $\mathrm{R}^{2}$ \\
\hline Total solids, \% & 34.86 & 0.35 & & 0.94 \\
Volatile solids, \% & 29.46 & 0.09 & & \\
Total minerals, \% & 5.420 & 0.095 & & \\
Macroelements, \% & & & 0.84 \\
$\mathrm{~N}$ & 4.246 & -0.171 & 0.004 & 1.0 \\
$\mathrm{P}$ & 0.923 & -0.037 & 0.0008 & 1.0 \\
$\mathrm{~K}$ & 2.310 & -0.083 & 0.002 & 1.0 \\
$\mathrm{Ca}$ & 0.522 & -0.026 & 0.001 & 0.90 \\
$\mathrm{Na}$ & 0.234 & -0.005 & - & 1.0 \\
$\mathrm{Mg}$ & 0.495 & -0.023 & 0.0005 & \\
$\mathrm{Microelements,} \mathrm{ppm}$ & & & & 1.0 \\
$\mathrm{Fe}$ & $1,004.5$ & -53.3 & 1.5 & 0.89 \\
$\mathrm{Zn}$ & 391.6 & -7.9 & - & 1.0 \\
$\mathrm{Cu}$ & 377.9 & -18.4 & 0.5 & \\
\hline
\end{tabular}


Qualitative feed restriction for heavy...

Table 8. Effect of qualitative feed restriction applied to heavy swines on the excretion of feces and fecal components

\begin{tabular}{|c|c|c|c|c|c|c|}
\hline \multirow[t]{2}{*}{ Daily excretion } & \multicolumn{5}{|c|}{ Qualitative feed restriction $1, \%$} & \multirow[t]{2}{*}{ Effect } \\
\hline & $0(n=9)$ & $5(n=9)$ & $10(n=9)$ & $15(n=10)$ & $20(n=10)$ & \\
\hline Feces, kg & $0.92 \pm 0.10$ & $1.32 \pm 0.10$ & $1.46 \pm 0.10$ & $1.75 \pm 0.10$ & $2.20 \pm 0.10$ & Lin. $* * *$ \\
\hline Total solids, $\%$ & $0.31 \pm 0.03$ & $0.47 \pm 0.03$ & $0.52 \pm 0.03$ & $0.66 \pm 0.03$ & $0.83 \pm 0.03$ & Lin. $* * *$ \\
\hline Volatile solids, $\%$ & $0.25 \pm 0.03$ & $0.38 \pm 0.03$ & $0.41 \pm 0.03$ & $0.52 \pm 0.02$ & $0.65 \pm 0.02$ & Lin. $* * *$ \\
\hline Total minerals, $\%$ & $46.3 \pm 5.2$ & $77.9 \pm 5.2$ & $90.6 \pm 5.1$ & $121.2 \pm 4.8$ & $156.4 \pm 5.2$ & Lin. $* * *$ \\
\hline \multicolumn{7}{|l|}{ Macroelements, $g$} \\
\hline $\mathrm{N}$ & $13.8 \pm 1.3$ & $15.9 \pm 1.3$ & $16.1 \pm 1.3$ & $17.5 \pm 1.2$ & $20.7 \pm 1.2$ & Lin. $* * *$ \\
\hline $\mathrm{P}$ & $2.92 \pm 0.20$ & $3.53 \pm 0.20$ & $3.35 \pm 0.20$ & $3.66 \pm 0.19$ & $4.23 \pm 0.19$ & Lin. $* * *$ \\
\hline $\mathrm{K}$ & $7.5 \pm 0.8$ & $9.1 \pm 0.8$ & $8.8 \pm 0.8$ & $10.1 \pm 0.8$ & $11.5 \pm 0.8$ & Lin. $* * *$ \\
\hline $\mathrm{Ca}$ & $1.66 \pm 0.12$ & $1.91 \pm 0.12$ & $1.76 \pm 0.12$ & $1.83 \pm 0.12$ & $2.15 \pm 0.12$ & Lin.* \\
\hline $\mathrm{Na}$ & $0.79 \pm 0.14$ & $0.95 \pm 0.14$ & $1.03 \pm 0.14$ & $1.09 \pm 0.13$ & $1.25 \pm 0.13$ & Lin.* \\
\hline $\mathrm{Mg}$ & $1.57 \pm 0.12$ & $1.80 \pm 0.12$ & $1.70 \pm 0.12$ & $1.71 \pm 0.11$ & $1.99 \pm 0.11$ & Lin.* \\
\hline \multicolumn{7}{|l|}{ Microelements, $\mathrm{mg}$} \\
\hline $\mathrm{Fe}$ & $312 \pm 32$ & $367 \pm 32$ & $324 \pm 32$ & $359 \pm 29$ & $438 \pm 29$ & Lin.* \\
\hline $\mathrm{Zn}$ & $176 \pm 15$ & $174 \pm 15$ & $164 \pm 15$ & $167 \pm 14$ & $201 \pm 14$ & - \\
\hline Mn & $86 \pm 8$ & $129 \pm 8$ & $145 \pm 8$ & $180 \pm 7$ & $242 \pm 7$ & Lin. $* * *$ \\
\hline $\mathrm{Cu}$ & $126 \pm 8$ & $144 \pm 8$ & $137 \pm 8$ & $125 \pm 7$ & $172 \pm 8$ & Lin.*** \\
\hline
\end{tabular}

adjusted means \pm standard error

$* \mathrm{P}<0.05 ; * * \mathrm{P}<0.01 ; * * * \mathrm{P}<0.001$

Table 9. Prediction equations of daily excretion of feces and fecal components of swines

\begin{tabular}{llll}
\hline Parameter & $\mathrm{b}_{0}$ & $\mathrm{~b}_{1}$ & $\mathrm{R}^{2}$ \\
\hline Feces, kg & 0.927 & 0.060 & 0.97 \\
Total solids, \% & 0.310 & 0.025 & 0.98 \\
Volatile solids, \% & 0.257 & 0.019 & 0.97 \\
Total minerals, \% & 45.8 & 5.2 & 0.98 \\
Macroelements, \% & & & \\
$\mathrm{N}$ & 13.72 & 0.31 & 0.91 \\
$\mathrm{P}$ & 2.99 & 0.055 & 0.83 \\
$\mathrm{~K}$ & 7.58 & 0.18 & 0.90 \\
$\mathrm{Ca}$ & 1.68 & 0.018 & 0.59 \\
$\mathrm{Na}$ & 0.810 & 0.21 & 0.97 \\
$\mathrm{Mg}$ & 1.60 & 0.015 & 0.58 \\
Microelements, ppm & & & \\
$\mathrm{Fe}$ & 311.2 & 4.9 & 0.61 \\
$\mathrm{Mn}$ & 83.94 & 7.26 & 0.96 \\
$\mathrm{Cu}$ & 126.2 & 1.5 & 0.36 \\
\hline
\end{tabular}

There was a linear increase in the contents of total solids $(\mathrm{P}<0.01)$, volatile solids $(\mathrm{P}<0.05)$, and total minerals $(\mathrm{P}<0.001)$. There was a linear decrease $(\mathrm{P}<0.01)$ in $\mathrm{Na}$ level, whereas fecal Mn concentration was not changed $(\mathrm{P}>0.1)$, as a function of the experimental diets. A quadratic response was observed in the fecal contents of $\mathrm{K}$ $(\mathrm{P}<0.05), \mathrm{Cu}(\mathrm{P}<0.01)$, and other microelements $(\mathrm{P}<0.001)$. There was an increase in the excretion of total solids, volatile solids, and total minerals $(\mathrm{P}<0.001)$, as well as a clear increase in $(\mathrm{P}<0.001) \mathrm{N}, \mathrm{P}, \mathrm{K}, \mathrm{Mn}$, and $\mathrm{Cu}$ excretion, whereas a less evident increase in $(\mathrm{P}<0.05) \mathrm{Ca}$,
$\mathrm{Na}, \mathrm{Mg}$, and Fe excretion. No effect $(\mathrm{P}>0.1)$ was observed on daily excretion of zinc.

\section{DISCUSSION}

Dietary fiber can be defined as a food fraction that is not digested by the enzymes produced by the animal, and that can be degraded by the action of microorganisms present in the digestive tract. It consists of polysaccharides, such as cellulose, hemicellulose, pectin, gums, and mucilages. Phenolic compounds, generally designated as lignin, are also considered as 
components of the fraction fiber (Silva, 1990). Therefore, the replacement of corn by fiber in swine diets impairs dry matter and energy digestibility due to the substitution of substrates, such as starch, by other components that are not digested by animal secretions.

Nevertheless, the action of fiber on dry matter and gross energy digestibility depends on the fiber. The inclusion of coffee hulls to swine diets reduced dry matter and energy digestibility (Oliveira et al., 2001), while this was not observed with the inclusion of citrus pulp. Different fibers present different capacities of being fermented by microorganisms in the digestive tract. Pectin, which is a significant component of citrus pulp fiber, is highly fermentable in swine, whereas coffee hulls and rice hulls have high cellulose and lignin contents, thereby causing a clearer reduction in diet digestibility. Cellulose is a fiber polysaccharide with low fermentability in the swine digestive tract (Dierick et al., 1989). According to Noblet and LeGoff (2001), energy digestibility is inversely proportional to the presence of lignin in the diets. Therefore, rice hulls efficiently reduced dietary energy content, with a reduction of almost $1 \%$ in digestible energy content for each $1 \%$ of qualitative feed restriction. This effectively means that the energy value of rice hulls was null, as considered in the formulation of the experimental diets.

Rice hulls consist mainly of fiber (Table 1), which presented very low digestibility. The inclusion of rice hulls to the diets, according to the qualitative feed restriction levels, resulted in a considerable increase in dietary fiber content; however, it virtually did not change digestible fiber content. Dietary ADFc level increased from 4.5 to $16.1 \%$ among treatments from 0 to $20 \%$ qualitative feed restriction, whereas digestible ADFc was not different among treatments. In addition to the presence of lignin, another factor that contributes to the low digestibility of rice hulls fiber is silica, an inert material resistant to digestion, and which is inversely proportional to the capacity of microorganisms to act on cellulose (Pond, 1988). Ash content of the rice hulls was approximately $16 \%$, of which almost $96 \%$ may consist of silica (Souza et al., 2002).
Qualitative feed restriction also reduced protein digestibility. However, as opposite to the findings of Huang et al. (2001), who observed a decrease in the ileal digestibility of amino acids as dietary protein linked to fiber increased, the amount of protein derived from rice hulls was very low in the experimental diets of the present experiment. Dietary fiber may interfere in the protein digestibility of other dietary components. Soluble fibers, consisting mainly of hemicellulose, gums, and mucilages, increase the viscosity of the intestinal content; thus, reducing enzyme action on dietary protein and increasing microbial activity (Johnston et al., 2003). However, the high contents of NDF, lignin, and silica in rice hulls characterize them as a source of insoluble fiber, and its negative effect on protein digestibility is related to an increase in endogenous nitrogen excretion, as observed by Schulze et al. (1994), when increasing NDF content was evaluated in swine diets.

It is important to consider the magnitude of the effect of feed restriction on digestibility parameters. The reduction in protein digestibility coefficient was $0.35 \%$ for each one percentage point of qualitative feed restriction increase, which is much lower than the reduction observed in values of digestibility coefficients of gross energy $(0.92 \%)$. As qualitative feed restriction aims at controlling energy intake, this low interference in dietary protein use is of interest.

The digestibility coefficient of ether extract was reduced in $1.8 \%$ for each one percentage point of qualitative feed restriction. Therefore, rice hulls fiber also influenced the digestibility of the oils present in other dietary ingredients, but more clearly as compared to protein. According to Noblet e LeGoff (2001), oils and fats are the main components that are affected by the presence of insoluble fiber.

The density of an ingredient is inversely proportional to its NDF content. Therefore, the inclusion of rice hulls, which has high NDF as compared to the other ingredients, allowed a high level of qualitative feed restriction. The amount of daily feed intake was not different among treatments, meaning that the increase in the levels of qualitative feed restriction promoted the intake of a higher feed volume, and hence, 
higher gastric development and a heavier stomach.

A marked increase in stomach weight relative to body weight was observed by Pond et al. (1988), who included alfalfa hay in swine diets, whereas there was no effect of coffee hulls on stomach weight (Oliveira et al., 2001). The different findings of these two studies are probably due to the higher density of the diets including coffee hulls as compared to rice hulls and alfalfa hay, if their NDF contents are taken into account.

Intestinal segments did present the same magnitude of response as the stomach, despite the increase in the digesta volume throughout the digestive tract, as there was a reduction in NDFc digestibility, that is increase of low density intestinal content. Gomes (1996) also observed increase in stomach weight after the inclusion of up to $30 \%$ alfalfa hay in gilt diets. Pond et al. (1988) also found a considerable increase both in the relative and the absolute weights of the colon and the cecum, in addition to that of the stomach when including alfalfa hay at $80 \%$ in swine diets. Therefore, the level of inclusion of the fibrous ingredient seems to determine its effect on the weight of organs of the intestinal tract.

On the other hand, the mentioned authors did not verify any reduction in cecum weight, and therefore, the difference in the used fiber sources must be taken into consideration. According to Glitso et al. (1998), the colon is virtually the only site that degrades fibers with a small fraction of soluble fiber, whereas the cecum is the main site of fibers containing higher content of soluble fiber. Therefore, ingredients with high soluble fiber tend to stimulate cecum development, while ingredients rich in insoluble fibers, such as rice hulls, do not. In addition, insoluble fibers increase the rate of fecal mass passage (Johnston et al., 2003), and thus, a high dietary content of this fraction may reduce the fermentative activity in cecum.

As to digestive tract glands, Pond al. (1988) and Gomes (1996) did not report any changes in absolute liver weight due to fiber inclusion in the diet. It must be noted that Gomes (1996) did not reduce dietary digestible energy content when including alfalfa hay, and therefore, energy intake remained the same. The liver is the main organ responsible for energy metabolism, as it synthesizes a significant fraction lipid and of lipid-carrying proteins. This is dependent on energy availability, which is reduced when qualitative feed restriction is applied. The weight of the pancreas, which is related to protein digestion, was not changed either by diet composition or energy level. Although dietary crude protein level was reduced as qualitative feed restriction increased, this variation was small, and the reduction in protein digestibility was not enough to affect pancreas weight.

According to digestibility findings, the worst digestibility coefficients resulted in an increase in the excretion of feces, and contents of total solids, total volatile solids, and total minerals. The same was observed by Massé et al. (2003), who included high fiber ingredients in sow diets.

On the other hand, concentrations of microelements in the feces were reduced, although these were similar among diets, except for $\mathrm{K}, \mathrm{Zn}$, and particularly $\mathrm{Mn}$, which dietary levels increased as qualitative feed restriction increased. Shaw et al. (2002) also verified that the inclusion of fiber from wheat bran in swine diets reduced the mineral content of feces, independently of the dietary mineral content. According to McDowell (1992), wheat bran and rice bran are the richest plant sources of $\mathrm{Mn}$, adding that the highest mineral concentrations are present in the outer layers, particularly in the hulls. Therefore, the high Mn concentration in rice hulls was responsible for the constant $\mathrm{Mn}$ fecal content among treatments, as opposed to the other evaluated minerals.

In addition to the mineral composition of rice hulls, there are interactions among minerals, due to the formation of insoluble complexes, to the competition for absorption in the intestine, and to the impact of fiber on their digestibility. This may have contributed to the higher or lower fecal content of these minerals as a function of qualitative feed restriction. Taking into account the dietary increment of $\mathrm{Mn}$, particularly, this mineral is characterized for reducing $\mathrm{Ca}$ and $\mathrm{P}$ availability. In addition, its own availability is decreased due to its interaction with dietary fiber and phytates, as occurs with the reduction in $\mathrm{Zn}$ availability by the presence of fiber (Underwood and Suttle, 1999). The effect of fiber on 
endogenous nitrogen excretion must also be considered.

The clear increase of $1.6 \%$ in increase of total fecal mineral for each one percent point of increase in qualitative feed restriction is opposed to the reduction in the fecal content of the most analyzed minerals. This response reflects the composition of rice hulls, which in high mineral content consists of approximately 95\% silica (Souza et al., 2002). Therefore, there was a clear increase in fecal silica content, a stabilization of $\mathrm{Mn}$ content, while the other analyzed minerals were reduced as qualitative feed restriction levels increased.

Another important factor to be taken into account is the use of animal production waste as crop fertilizer. However, this waste must be underwent to a stabilization process determined by microorganism action, which allows this material to be used as fertilizer. Two aspects of fecal composition are important for this process: optimal carbon: nitrogen ratio $(\mathrm{C}: \mathrm{N})$, which must be around 30, and a nitrogen: phosphorus ratio (N:P) of approximately 5. Swine waste usually has low carbon: nitrogen ratio (Oliveira, 1993). Based on Table 3, fecal N:P ratios were 4.66, $4.51,4.75,4.78$, and 4.88 for the applied levels of qualitative feed restriction. Therefore, the ratio improved with feed restriction levels between 10 and 20\%. Similarly, higher fiber intake increases waste $\mathrm{C}: \mathrm{N}$ ratio, which means waste stabilization process is improved as qualitative feed restriction increases; however, the presence of lignin, a significant component of rice hulls, may impair this process (Oliveira 1993). In addition, the silica present in the feces due to the inclusion of rice hulls in the diets is an important element in crop fertilization, promoting the resistance, particularly of grasses, against several diseases, as described by Barbosa Filho et al. (2000).

The increase of crop area that can be fertilized with feces may be a problem for farms that do not have sufficient land to cope with the amount of feces produced. However, when there is enough available land, the use of rice hulls for qualitative feed restriction may be environmentally interesting for the disposal of the high quantity of waste produced in swine farms (Della et al., 2001). The application of the concept of qualitative feed restriction by using rice hulls reduce the digestibility of all dietary components, particularly of lipids and energy. It also promotes slight stimulation of the fermentation process, which increases the excretion of feces and its components, despite diluting the elements present in the feces.

\section{REFERENCES}

BARBOSA FILHO, M.P.; SNYNDER, G.H.; PRABHU, A.S. et al. Importância do silício para a cultura do arroz. Inform. Agron., v.89, p.1-8, 2000.

BATAGLIA, O.G.; FURLANI, A.M.C.; TEIXEIRA, J.P.F. et al. Métodos de análises químicas de plantas. Campinas: Instituto Agronômico, 1993.

DELLA, V.P.; KÜHN, I.; HOTZA, D. Caracterização de cinza de casca de arroz para uso como matéria-prima na fabricação de refratários de sílica. Quím. Nova, v.24, p.778782, 2001.

DIERICK, N.A.; VERVAEKE, I.J.; DEMEYER, D.I. et al. Approach to the energetic importance of fibre digestion in pigs. I. Importance of fermentation in the overall energy supply. Anim. Feed Sci. Technol., v.23, p.141-167, 1989.

FENTON, T.W.; FENTON, M. An improved procedure for the determination of chromic oxide in feed and feces. Can. J. Anim. Sci., v.59, p.631-634, 1979.

GLITSO, L.V.; BRUNSGRAAD, G.; HOJSGAARD, S. et al. Intestinal degradation in pigs of rye dietary fibre with different structural characteristics. Br. J. Nutr., v.80, p.457-468, 1998.

GOMES, J.D.F. Efeitos do incremento da fibra em detergente neutro, sobre parâmetros de desempenho, de digestibilidade dos componentes dietéticos e da morfologia intestinal de marrãs. 1996, 95f. Tese (Doutorado) - Faculdade de Medicina Veterinária e Zootecnia, Universidade Estadual Paulista, Botucatu.

HUANG, S.X.; SAUER, W.C.; MARTY, B. Ileal digestibilities of neutral detergent fiber, crude protein, and amino acids associated with neutral detergent fiber in wheat shorts for growing pigs. J. Anim. Sci., v.79, p.2388-2396, 2001. 
JOHNSTON, L.J.; RENTERIA, A.; SHURSON, J. Feeding by-products high in concentration of fiber to nonruminants. In: NATIONAL SYMPOSIUM ON ALTERNATIVE FEEDS FOR LIVESTOCK AND POULTRY, 3., 2003, Kansas City. Disponível em $<$ www.wcroc.coafes.umn.edu $>$. Acessado em: 11 jan. 2005.

MASSÉ, D.I.; CROTEAU, F.; MASSÉ, F. et al. Effect of dietary fiber incorporation on the characteristics of pregnant sows slurry. Can. Bios. Engin., v.45, p.7-12, 2003.

MCDOWELL, L.R. Minerals in animal and human nutrition. London: Academic Press, 1992.

NOBLET, J.; LEGOFF, G. Effect of dietary fibre on the energy value of feeds for pigs. Anim. Feed Sci. Technol., v.90, p.35-52, 2001.

OETTING, J.J. Avaliação de diferentes marcadores para a determinação da digestibilidade e taxa de passagem do alimento em suínos. 2002, 57f. Dissertação (Mestrado) Centro de Energia Nuclear na Agricultura da Escola Superior de Agricultura "Luiz de Queiroz", Universidade de São Paulo, Piracicaba.

OLIVEIRA, P.A. Manual de manejo e utilização dos dejetos de suínos. Concórdia: Embrapa Suínos e Aves, 1993.

OLIVEIRA, S.; FIALHO, E.T.; LIMA, J.A.F. et al. Substituição do milho por casca de café em rações isoenergéticas para suínos em crescimento e terminação. Cienc. Agrotec., v.25, p.424-436, 2001.
PENZ JÚNIOR, A.M. A influência da nutrição na preservação do meio ambiente. In: SIMPÓSIO INTERNACIONAL DE SUINOCULTURA, 5., 2000, Concórdia. Anais... Concórdia: Embrapa Suínos e Aves, 2000. p.53-69.

POND, W.G.; JUNG, H.G.; VAREL, V.H. Effect of dietary fiber on young genetically lean, obese and contemporary pigs: body weight, carcass measurements, organ weights and digesta content. J. Anim. Sci., v.66, p.699-706, 1988.

SARRUGE, J.R.; HAAG, H.P. Análises químicas em plantas. Piracicaba: ESALQ, 1974.

SHAW, D.T.; ROZEBOOM, D.W.; HILL, G.M. et al. Impact of vitamin and mineral supplement withdrawal and wheat middling inclusion on finishing pig growth performance, fecal mineral concentration, carcass characteristics, and the nutrient content and oxidative stability of pork. J. Anim. Sci., v.80, p.2920-2930, 2002.

SCHULZE, H.; LEEUWEN, P.; VAN, VERSTEGEN, M.W.A. Effect of level dietary neutral detergent fiber on ileal apparent digestibility and ileal nitrogen losses in pigs. $J$. Anim. Sci., v.72, p.2362-2368, 1994.

SILVA, D.J. Análise de alimentos - métodos químicos e biológicos. 2.ed. Viçosa: UFV, 1990.

SOUZA, M.F.D.E.; MAGALHÃES, W.L.E.; PERSEGUIL M.C. Silica derived from burned rice hulls. Mat. Res., v.5, p.467-474, 2002.

UNDERWOOD, E.J., SUTTLE, N.F. The mineral nutrition of livestock. 3.ed. Wallingford: CABI Publishers, 1999. 